\title{
SISTEM PENDUKUNG KEPUTUSAN PENENTUAN PENERIMAAN BEASISWA BERBASIS WEB PADA SMK NEGERI 1 TALANGPADANG MENGGUNAKAN METODE Analytical Hieararchy Process (AHP)
}

\author{
Rima Mawarni ${ }^{1}$, Meri Parida ${ }^{2}$ \\ Sistem Informasi ${ }^{12}$ \\ STMIK Dian Cipta Cendikia Kotabumi ${ }^{12}$ \\ Jl. Negara No. 03 Candimas Kotabumi - Lampung Utara \\ E-mail : rima@dcc.ac.id ${ }^{1}$, merri.parida@dcc.ac.id ${ }^{2}$
}

\begin{abstract}
ABSTRAK
Pengolahan data beasiswa di SMK Negeri 1 Talang padang pada umumnya masih menggunakan Microsoft Excel, sehingga untuk pengolahan datanya membutuhkan waktu yang lama. Permasalahanya yang sering muncul yaitu tercecernya file pendistribusian penerimaan beasiswa setiap tahunnya. Kriteria seleksi beasiswa terdiri dari Prestasi Akademik, Prestasi Non Akademik, Kepribadian, Jarak tempuh, Nilai raport, Keorganisasian, Tanggungan orang tua, Penghasilan orang tua, dan Status orang tua.

Metode yang digunakan dalam sistem pengambilan keputusan ini adalah metode Analytical Hierarchy Process (AHP) yang ditemukan oleh Thomas L. Saaty. AHP sendiri dapat membantu dalam menentukan prioritas dari beberapa kriteria dengan melakukan analisa perbandingan berpasangan dari masing-masing kriteria yang sudah ditentukan.
\end{abstract}

Kata kunci: system pendukung keputusan, beasiswa prestasi, smk $\mathrm{n} 1$ talang padang, mysql, php script, ahp.

\section{ABSTRACT}

Processing of scholarship data in SMK 1 Talangpadang generally still uses Microsoft Excel, while for data processing takes a long time. The problem that often arises is the scattering of the file for distributing scholarship receipts every year. This scholarship consists of Academic Achievement, Non Academic Achievement, Personality, Mileage, Report Card, Organizations, Dependent Parents, Parent's Income, and Parent's Status.

The method used in this study is the Analytical Hierarchy Process (AHP) Method found by Thomas L. Saaty. AHP can also help in determining several criteria by using a different analysis from each of the specified sources.

Keywords: decision support systems, achievement scholarships, junior high school, mysql, php script, ahp.

\section{PENDAHULUAN}

1.1 Latar Belakang

Pada era globalisasi sekarang ini, pendidikan merupakan hal yang penting dalam kehidupan karena menjadi jembatan penghubung anak dengan masa depannya. Pendidikan merupakan salah satu pembentuk pondasi bagi tubuh dan berkembangnya seorang anak untuk memperoleh masa depan yang lebih baik.

Beasiswa adalah bantuan pendidikan yang diberikan tidak hanya kepada siswa yang orang tua atau walinya kurang mampu tetapi juga kepada siswa yang berprestasi. Pengolahan data beasiswa di SMK Negeri 1 Talangpadang pada umumnya masih menggunakan Microsoft Excel, sehingga untuk pengolahan datanya membutuhkan waktu yang lama. Metode yang digunakan dalam sistem pengambilan keputusan ini adalah metode Analytical Hierarchy Process (AHP) yang ditemukan oleh Thomas L.Saaty.

Dengan melihat masalah yang ada dalam pengambilan keputusan dalam pemilihan penerima beasiswa, sistem pendukung keputusan dengan menggunakan metode AHP dirasa tepat untuk digunakan dalam membantu pengambilan keputusan untuk menentukan penerima beasiswa. Diharapkan hasil dalam 
penelitian ini dapat membantu pengambil keputusan dalam menentukan penerima beasiswa.

\subsection{Identifikasi Masalah}

Bagaimana merancang dan mengimplementasikan sistem pendukung keputusan yang dapat memperhitungkan segala kriteria yang mendukung pengambilan keputusan guna membantu, mempercepat dan mempermudah proses pengambilan keputusan dalam penentuan penerimaan beasiswa lebih obyektif sesuai dengan urutan terbaik siswa yang berhak dan layak menerima beasiswa dengan menggunakan metode AHP.

\subsection{Tujuan Penelitian}

a. Untuk mempermudah proses penentuan penerimaan beasiswa pada SMK Negeri 1 Talangpadang.

b. Untuk membuat sistem pengolahan data yang mampu menjawab permasalahanpermasalahan yang belum dapat dipecahkan oleh sistem yang sedang berjalan pada obyek penelitian.

c. Untuk mempercepat dan mempermudah pencarian informasi data pendistribusian beasiswa.

d. Untuk keamanan data pendistribusian beasiswa.

\subsection{Tinjauan Pustaka}

1. Pengertian Sistem

Pengertian Sistem menurut Yakub yang berjudul "Pengantar Sistem Informasi" ( 2012: 01 ) Sistem adalah suatu jaringan kerja dari prosedur - prosedur yang saling berhubungan, terkumpul bersama - sama untuk melakukan suatu kegiatan atau untuk tujuan tertentu.

\section{Sistem Pendukung Keputusan}

Sistem pendukung keputusan (decision support system atau disingkat $D S S$ ) adalah bagian dari sistem informasi berbasis komputer termasuk sistem berbasis pengetahuan (manajemen pengetahuan) yang dipakai untuk mendukung pengambilan keputusan dalam suatu organisasi atau perusahaan. Konsep Sistem pendukung keputusan (Decision Support System) pertama kali digunakan pada awal tahun 1970 oleh Michael S. Scott Morton dengan menggunakan istilah "management decision system". Konsep ini merupakan sebuah mekanisme yang berbasis pada penggunaan data dan model untuk memecahkan permasalahan-permasalahan yang tidak terstruktur.[3]

Karakteristik dari sistem pendukung keputusan (Decision Support System) adalah sebagai berikut :

1. Tujuan utama dari Sistem Pendukung Keputusan adalah untuk memperbaiki mutu keputusan serta performance. Sistem Pendukung Keputusan tidak hanya sekedar menyajikan informasi yang lebih banyak, lebih baik dan lebih akurat pada waktu yang tepat saja.

2. Sistem Pendukung Keputusan ditujukan untuk environment yang komplek, kurang terstruktur dan bahkan politis sifatnya.

3. Sistem Pendukung Keputusan bertumpu pada laporan perkecualian dan macamnya untuk menunjang proses identifikasi masalah.

4. Sistem Pendukung Keputusan berkombinasi "modelling" dan teknik-teknik analisa yang lain dengan fungsi penyajian kembali data.

5. Sistem Pendukung Keputusan berfokus pada prinsip "mudah dipakai" dan "fleksibel" dalam berhadapan dengan pemakai tertentu atau sekelompok pemakai.

6. Proses Pengambilan Keputusan

3. Metode Analytic Hierarchy Process (AHP) AHP merupakan suatu model pendukung keputusan yang dikembangkan oleh Thomas L. Saaty. Model pendukung keputusan ini akan menguraikan masalah multi faktor atau multi kriteria yang kompleks menjadi suatu hirarki, menurut Saaty, hirarki didefinisikan sebagai suatu representasi dari sebuah permasalahan yang kompleks dalam suatu struktur multi level dimana level pertama adalah tujuan, yang diikuti level faktor, kriteria, sub kriteria, dan seterusnya ke bawah hingga level terakhir dari alternatif.[5]

AHP sering digunakan sebagai metode pemecahan masalah dibanding dengan metode yang lain karena alasan-alasan sebagai berikut :

a. Struktur yang berhirarki, sebagai konsekuesi dari kriteria yang dipilih, sampai pada subkriteria yang paling dalam. 
b. Memperhitungkan validitas sampai dengan batas toleransi inkonsistensi berbagai kriteria dan alternatif yang dipilih oleh pengambil keputusan.

c. Memperhitungkan daya tahan output analisis sensitivitas pengambilan keputusan.

\section{Extreme Proramming}

Extreme Proramming merupakan salah satu model pengembangan sistem dari beberapa model dalam pendekatan Agile Process (jenis pengembangan sistem jangka pendek yang fleksibel). Di dalam pengembangan sistem yang menggunakan Extreme Programming terdapat empat tahapan, yaitu: Planning, Design, Coding, dan Testing (Pressman, 2005). Untuk lebih jelasnya dapat dilihat pada gambar 1.1. [4]

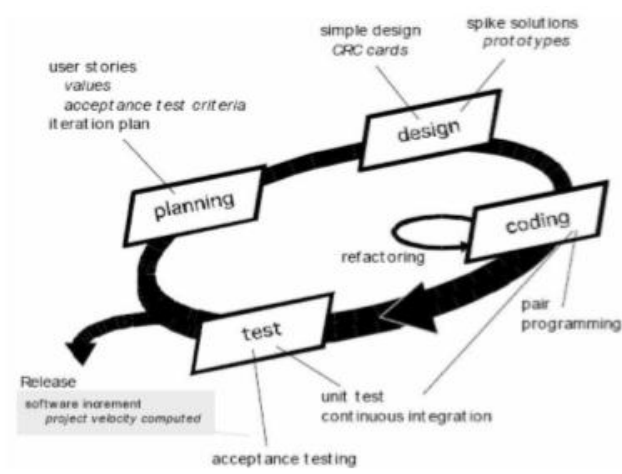

Gambar 1.1 Extreme Programming Process

\section{METODELOGI PENELITIAN}

\subsection{Desain Uji Coba}

Dalam pengembangan dengan metode AHP terdapat beberapa prinsip dasar yang harus dilakukan:

1) Decomposition (Membuat Heararchy) Prinsip ini merupakan pemecahan persoalan-persoalan yang utuh menjadi unsur-unsurnya ke bentuk hirarki proses pengambilan keputusan dimana setiap unsure atauelemen saling berhubungan. Jika ingin mendapatkan hasil yang akurat, pemecahan dilakukan terhadap unsurunsurnya sampai tidak mungkin dilakukan pemecahan yang lebih lanjut sehingga didapatkan beberapa tingkatan dari persoalan yang ada. Struktur hirarki keputusan tersebut dapat dikatakan Complete dan ncomplete. Suatu hirarki disebut complete bila semua elemen pada suatu tingkat berhubungan dengan semua elemen pada tingkat berikutnya, sementara hirarki keputusan incomplete adalah kebalikan dari complete.

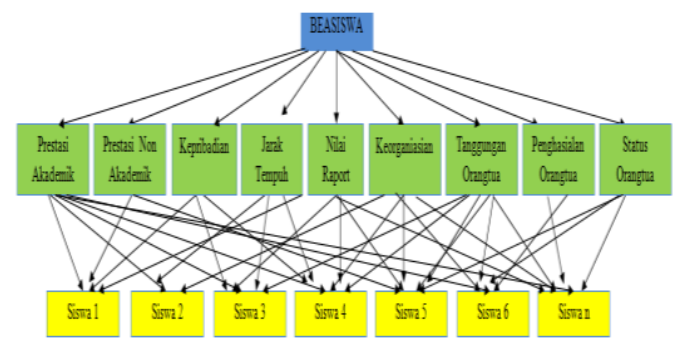

Gambar 2.1 Struktur Heararchy

2) Comparative Judgement (Penilaian Kriteria dan Alternatif)

Prinsip ini memberikan penilaian tentang kepentingan relatif dua elemen pada suatu tingkat tertentu dalam kaitannya dengan tingkat yang diatasnya. Penilaian ini merupakan inti dari penggunaan metode AHP. Penilaian ini dapat disajikan dalam bentuk matriks yang disebut matriks pairwise comparison yaitu matriks perbandingan berpasangan yang memuat tingkat preferensi beberapa alternatif untuk kriteria. Skala preferensi dengan skala 1 menunjukan tingkat paling rendah sampai dengan skala 9 tingkatan paling tinggi. Untuk skala perbandingan berpasangan disajikan dalam tabel berikut :[3]

Tabel 2.1 Skala Penilaian Perbandingan Berpasangan

\begin{tabular}{|c|l|}
\hline Integritas & \multicolumn{1}{|c|}{ Keterangan } \\
\hline 1 & $\begin{array}{l}\text { Kedua elemen sama } \\
\text { pentingnya }\end{array}$ \\
\hline 3 & $\begin{array}{l}\text { Elemen yang satu sedikit lebih } \\
\text { penting daripada elemen yang } \\
\text { lainnya }\end{array}$ \\
\hline 5 & $\begin{array}{l}\text { Elemen yang satu lebih penting } \\
\text { daripada yang lainnya }\end{array}$ \\
\hline 7 & $\begin{array}{l}\text { Satu elemen jelas lebih mutlak } \\
\text { penting daripada elemen } \\
\text { lainnya penting }\end{array}$ \\
\hline $2,4,6,8$ & $\begin{array}{l}\text { Satu elemen mutlak } \\
\text { daripada elemen lainnya }\end{array}$ \\
\hline $\begin{array}{l}\text { Nilai-nilai antara dua nilai } \\
\text { pertimbangan-pertimbangan } \\
\text { yang berdekatan }\end{array}$ \\
\hline
\end{tabular}

Dalam penilaian kepentingan relatif dua elemen berlaku aksioma reciprocal artinya jika elemen i dinilai 3 kali lebih penting dibanding $\mathrm{j}$, maka elemen $\mathrm{j}$ harus sama dengan $1 / 3$ kali pentingnya dibanding elemen i. Di 
samping itu, bila dua elemen dibandingkan menghasilkan angka 1 berarti sama penting.

Penghitungan konsistensi logis dilakukan dengan mengikuti langkah-langkah sebagai berikut

a. Mengalikan matriks dengan proritas bersesuaian.

b. Menjumlahkan hasil perkalian per baris.

c. Hasil penjumlahan tiap baris dibagi prioritas bersangkutan dan hasilnya dijumlahkan.

d. Hasil c dibagi jumlah elemen, akan didapat $\lambda$ maks (eigen value).

e. Indeks Konsistensi $(\mathrm{CI})=(\lambda$ maksn) / (n-1).

f. Rasio Konsistensi = CI/ RI, di mana RI adalah indeks random konsistensi. Jika rasio konsistensi $\leq 0.1$, hasil perhitungan data dapat dibenarkan.

3) Synthesis of Priority (Menentukan Prioritas) Pada prinsip ini menyajikan matriks pairwise comparison yang kemudian dicari eigen vektornya untuk mendapatkan local priority. Karena matriks pairwise comparison terdapat pada setiap tingkat, maka untuk mendapatkan global priorty dapat dilakukan sintesa diantara local priority.

\section{4) Logical Consistency (Konsistensi Logis)}

Merupakan karakteristik yang paling penting. Hal ini dapat dicapai dengan mengagresikan seluruh vektor eigen yang diperoleh dari tingkatan hirarki dan selanjutnya diperoleh suatu vektor composite tertimbang yang menghasilkan urutan pengambilan keputusan.

Jenis data yang digunakan dalam penelitian ini meliputi parameter prestasi akademik, prestasi non akademik, kepribadian, jarak tempuh, nilai raport, keorganisasian, jumlah tanggungan orang tua, jumlah penghasilan orang tua, status orang tua. Masing-masing kriteria diberikan 4 intensitas yaitu sangat baik, baik, cukup, dan kurang. Struktur heararky bisa dilihat pada Tabel 2.2

Tabel 2.2 Penilaian berdasarkan parameter

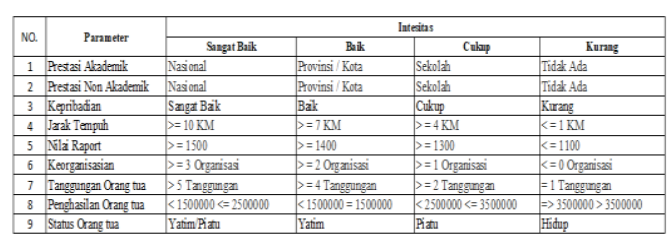

2.2 Teknik Pengumpulan Data

Metode pengumpulan data dalam penelitian ini adalah:[1]

1. Metode wawancara (Interview)

Untuk mendapat data-data sebagai sumber fakta penulis melakukan wawancara sebagai langkah untuk mendapat informasi dari berbagai pihak yang bersangkutan.

2. Metode pengamatan langsung (Observasi) Cara pengambilan data dengan terjun langsung ke lapangan dengan melaksanakan penelitian, penulis mendapat kemudahan dalam mengumpulkan data karena mendapat keleluasaan untuk mencari informasi dari berbagai pihak yang bersangkutan.

Perolehan Data :

a. Prestasi akademik, Prestasi non akademik, Keorganisasian, Nilai raport, Jumlah tanggungan orang tua, Jumlah penghasilan orang tua, dan Status orang tua: diperoleh dari formulir yang dibagikan kepada setiap siswa.

b. Nilai Kepribadian di peroleh dari guru bimbingan konseling yaitu dengan menghitung beberapa indicator diantaranya tanggung jawab, saling menghargai, percaya diri, santun dan kompetitif.

\subsection{Penentuan Kriteria Beasiswa}

Dalam penyeleksian beasiswa dengan menggunakan metode AHP diperlukan kriteriakriteria dan bobot untuk melakukan perhitungannya sehingga akan didapat alternatif terbaik.

Tabel 2.3 Kriteria Beasiswa

\begin{tabular}{|c|c|}
\hline Kriteria & Keterangan \\
\hline $\mathrm{K}_{1}$ & Prestasi Akademik \\
\hline $\mathrm{K}_{2}$ & Prestasi Non Akademik \\
\hline $\mathrm{K}_{3}$ & Kepribadian \\
\hline $\mathrm{K}_{4}$ & Jarak Tempuh \\
\hline $\mathrm{K}_{5}$ & Nilai Raport \\
\hline $\mathrm{K}_{6}$ & Keorganisasian \\
\hline $\mathrm{K}_{7}$ & Jumlah Tanggungan Orang tua \\
\hline $\mathrm{K}_{8}$ & Penghasilan Orang Tua \\
\hline $\mathrm{K}_{9}$ & Status Orang Tua \\
\hline
\end{tabular}




\subsection{Use Case Sistem}

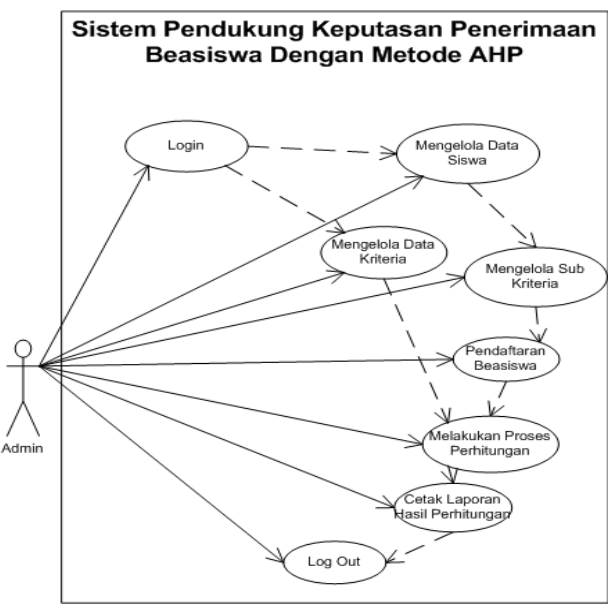

2.5 Squence Diagram Login Sistem

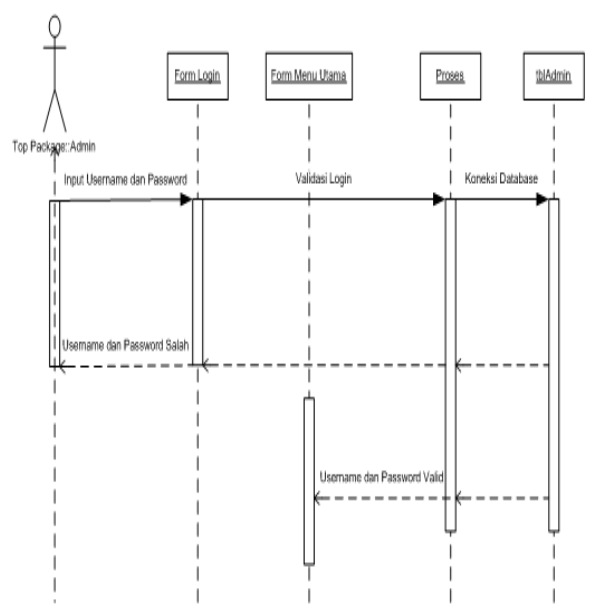

Gambar 2.4 Squence Diagram Login Sistem

2.6 Squence Diagram Data Siswa

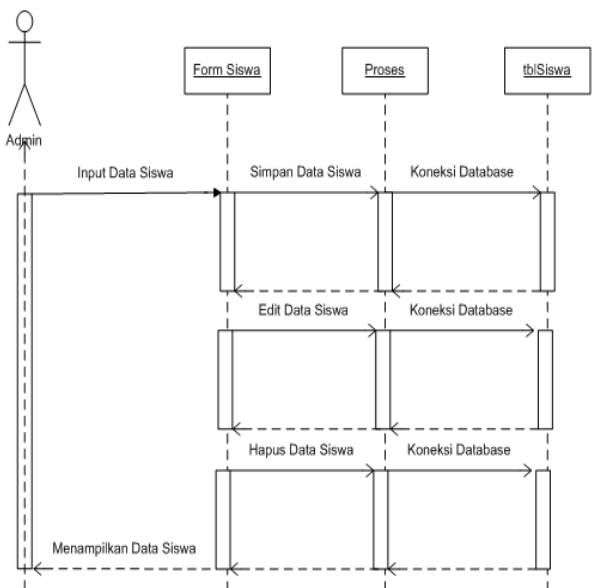

Gambar 2.5 Squence Diagram Data Siswa
2.7 Squence Diagram Data Kriteria

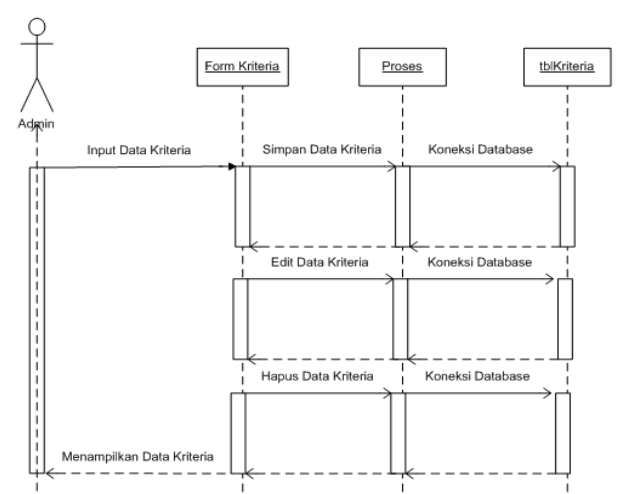

Gambar 2.6 Squence Diagram Data Kriteria

2.8 Squence Diagram Perhitungan Beasiswa

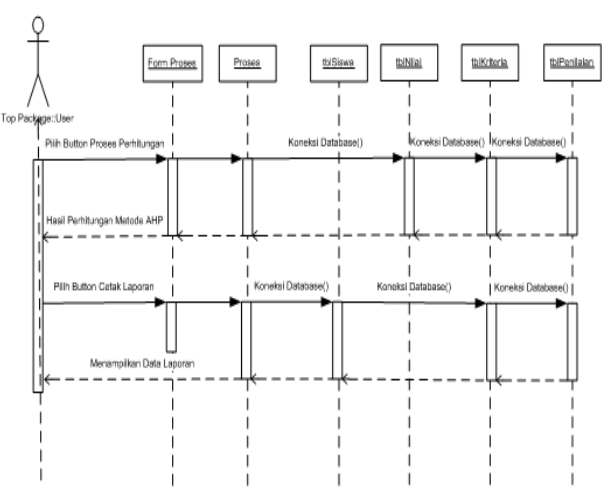

Gambar 2.7 Squence Diagram Perhitungan beasiswa

2.9 Class Diagram

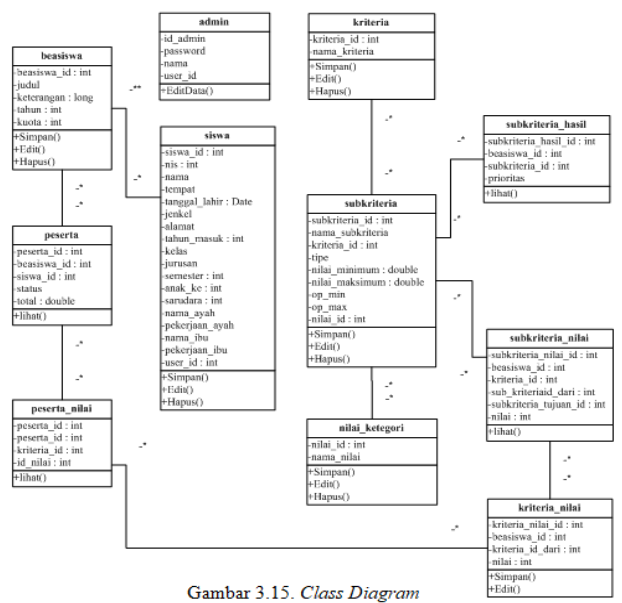

Gambar 2.8 Class Diagram

$$
\text { 153|S TMIK Dian Cipta Cendikia Kotabumi }
$$


2.10 Normalisasi

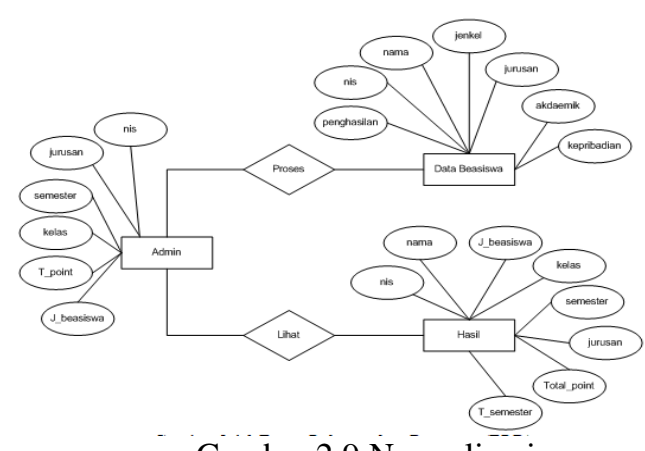

Gambar 2.9 Normalisasi

3. HASIL DAN PEMBAHASAN

3.1 Kebutuhan Perangkat Keras dan Perangkat Lunak

Berdasarkan implementasi sistem yang dilakukan penulis, perangkat keras yang dibutuhkan untuk persiapan sistem yang diusulkan. Perangkat keras yang dibutuhkan adalah seperangkat komputer dengan spesifikasi sebagai berikut :

1. Processor Intel Core Duo

2. RAM 2 GB

3. Hardisk $500 G B$

4. Keyboard, VGA, Mouse, dan Printer tipe standar

Perangkat lunak / Software yang dibutuhkan untuk penerapan sistem pendukung keputusan penentuan penerimaan beasiswa ini adalah :

1. Sistem Operasi Windows 7

2. Database MySQL sebagai DBMS (Data Base Management System)

3. $P H P$ sebagai pengakses database $M y S Q L$

4. Adobe Dreamweaver CS5 sebagai desain tampilan sistem.

5. Browser ( Mozilla Firefox / Google Chrome )

6. Хатрp V.5.6.28

3.2 Tampilan Form Login

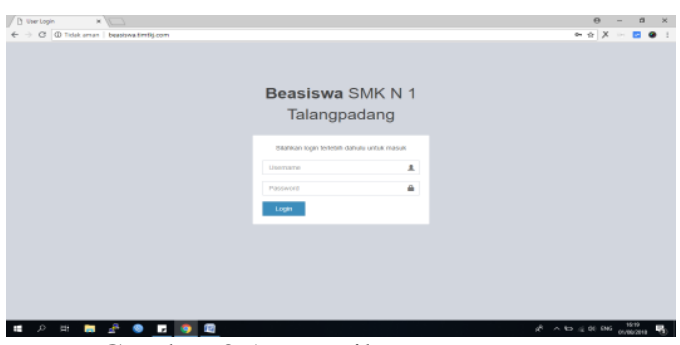

Gambar 3.1 Tampilan Form Login
3.3 Tampilan Form Input Data Siswa

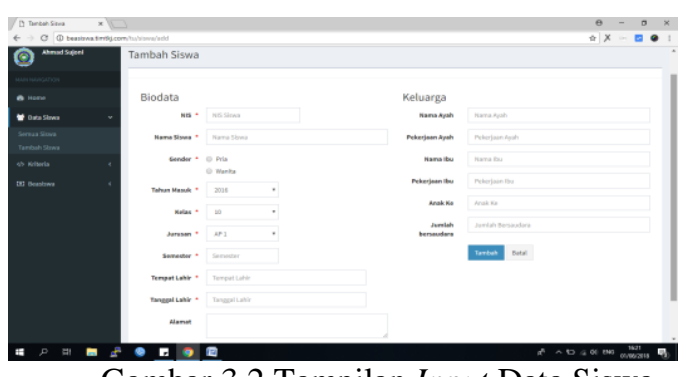

Gambar 3.2 Tampilan Input Data Siswa

3.4 Tampilan Form Pebobotan

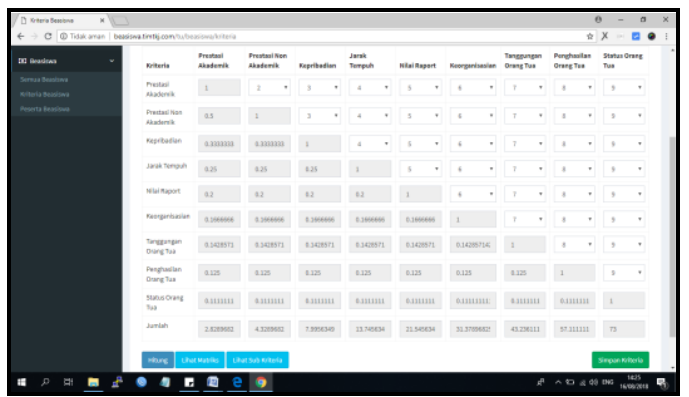

Gambar 3.3 Tampilan Form Pembobotan

3.5 Tampilan Form Input Beasiswa

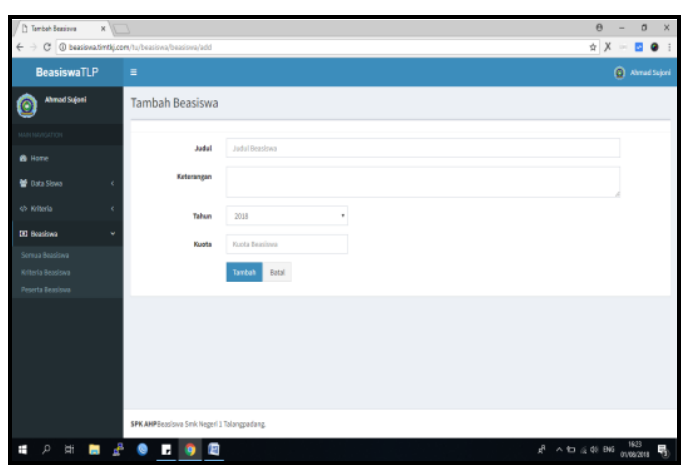

Gambar 3.4 Tampilan Form Input Beasiswa

3.6 Tampilan Form Input Peserta

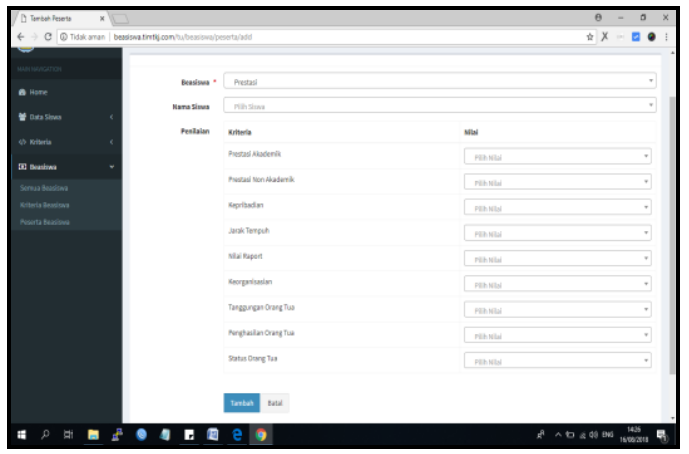

Gambar 3.5 Tampilan Form Input Peserta 


\subsection{Tampilan Laporan Seleksi Beaiswa}

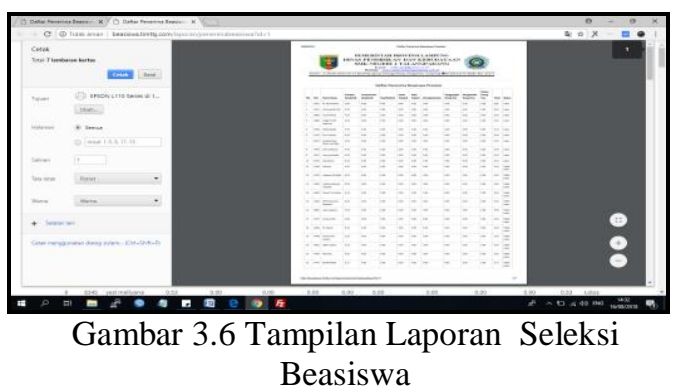

3.8 Skenaria Pengujian Black Box

Skenario pengujian menggunakan metode Black Box dimana pengujian yang dilakukan adalah pengujian fungsionalitas dari sistem, apakah sistem berfungsi dengan hasil yang diinginkan atau tidak. Pada aplikasi aplikasi Sistem Pendukung Keputusan Penentuan Penerimaan Beasiswa dengan Menggunakan Metode AHP Pada SMK Negeri 1 Talangpadang ini, pengujian merujuk pada fungsi-fungsi yang dimiliki sistem, kemudian membandingkan hasil keluaran dengan hasil yang diharapkan. Bila hasil yang diharapkan sesuai dengan hasil pengujian, berarti perangkat lunak sesuai dengan desain yang telah ditentukan sebelumnya. Bila belum sesuai maka perlu dilakukan pengecekan lebih lanjut dan perbaikan.

Tabel 3.1 Pengujian Black Box

\begin{tabular}{|c|c|c|}
\hline No & Kelas Uji & $\begin{array}{c}\text { Kriteria Evaluasi } \\
\text { Kerja }\end{array}$ \\
\hline 1 & $\begin{array}{l}\text { Authentifika } \\
\text { si } \\
\text { Administrato } \\
\mathrm{r}\end{array}$ & $\begin{array}{lr}\text { Simulasi } & \text { system } \\
\text { memeriksa } & \text { proses } \\
\text { login administrator, } \\
\text { berhasil atau tidak, } \\
\text { kemudian } \\
\text { menyimpan session } \\
\text { administrator } r \text { pada } \\
\text { saat proses login, } \\
\text { dan mematikan } \\
\text { session saat } \\
\text { administrator sudah } \\
\text { logout, sehingga } \\
\text { sistem tidak bisa } \\
\text { dibuka lagi kecuali } \\
\text { harus login kembali }\end{array}$ \\
\hline 2 & $\begin{array}{l}\text { Pengolahan } \\
\text { data }\end{array}$ & $\begin{array}{lr}\text { Sistem } & \text { dapat } \\
\text { menampilkan profil } \\
\text { siswa, menambah } \\
\text { menghapus dan } \\
\text { mengubah data siswa }\end{array}$ \\
\hline 3 & Pengolahan & Sistem dapat \\
\hline
\end{tabular}

\begin{tabular}{|c|c|c|}
\hline & $\begin{array}{l}\text { data } \\
\text { kriteria }\end{array}$ & $\begin{array}{lr}\text { menampilkan } & \text { data } \\
\text { kriteria, } & \text { dan } \\
\text { menghapus } & \text { data } \\
\text { kriteria serta bobot } \\
\text { kriteria }\end{array}$ \\
\hline & $\begin{array}{l}\text { Sistem dapat } \\
\text { menampilka } \\
\mathrm{n} \text { data } \\
\text { kriteria, dan } \\
\text { menghapus } \\
\text { data kriteria } \\
\text { serta bobot } \\
\text { kriteria }\end{array}$ & $\begin{array}{lr}\text { Sistem } & \text { dapat } \\
\text { menampilkan } & \text { data } \\
\text { subkriteria, } & \text { dan } \\
\text { menghapus } & \text { data } \\
\text { subkriteria } & \text { serta } \\
\text { bobot subkriteria } & \end{array}$ \\
\hline 4 & $\begin{array}{l}\text { Pengolahan } \\
\text { intensitas } \\
\text { siswa }\end{array}$ & $\begin{array}{lr}\text { Sistem } & \text { dapat } \\
\text { menampilkan pilihan } \\
\text { untuk nilai siswa } \\
\text { dan akan dihitung } \\
\text { total bobot nilai } \\
\text { perkriteria } \\
\text { subkriteria }\end{array}$ \\
\hline
\end{tabular}

\section{KESIMPULAN}

Setalah melakukan penelitian pada SMK N 1 Talangpadang, maka penulis menarik kesimpulan sebagai berikut :

1. Aplikasi yang dibangun menggunakan $P H P$ Script dan database MySQL, sehingga memudahkan user dalam menggunakannya.

2. Aplikasi sistem pendukung keputusan yang dibangun dapat memberikan kemudahan serta memperkecil kesalahan yang mungkin terjadi dalam proses pemilihan calon penerimaan beasiswa pada SMK Negeri 1 Talangpadang.

3. Metode pembobotan yang digunakan adalah metode Analityc Hierarchy Prosess $(A H P)$ sehingga hasil implementasi sistem dapat mempermudah menyeleksi siswa untuk mendapatkan beasiswa dengan data penilaian menurut kriteria yang telah ditetapkan.

\section{DAFTAR PUSTAKA}

[1] Abadi, Friska. "Penentuan Penerima Bantuan Dana untuk Sekolah Menengah Di Kab. Banjar Menggunakan Metode AHPTOPSIS Dengan Pendekatan Fuzzy." (2016).

[2] Ariyadi, Bagas Dista. "Sistem Pendukung keputusan Seleksi Penerima Beasiswa Pada Sma 1 Boja Dengan Menggunakan Metode Analytical Hierarchy Process (AHP)." 
Universitas Dian Nuswantoro (2013)

[3] Iskandar, Fauziah Mayasari, Arief Andy Soebrot02, and Rekyan Regasari.

"Sistem Pendukung Keputusan Seleksi Beasiswa PPA Dan BBM Menggunakan Metode Fuzzy AHP." Smatika Jurnal 3 (2013).

[4] Sidiq, Abdul Hafidh. "Rancang Bangun Sistem Informasi Administrasi Beasiswa UIN Sunan Kalijaga Menggunakan Pendekatan Agile Process dengan Model Extreme Programming." (2013).

[5] Saaty, T.L., (2009), "Decision Making for Leaders The Analytical Hierarchy Process", University of Pittsburgh, USA 